\section{Thermal conductivity of wood-plastic composites as insulation panels: theoretical and experimental analysis}

Hadeel Mahmood MUSSA - Mustansiriyah University, College of Engineering, Iraq - hadeelmussa52@gmail.com

TAWfEeq WASmı M. SALIH - Mustansiriyah University, College of Engineering, Iraq - tawfeeqwasmi@uomustansiriyah.edu.iq

Érkezett: 2020. 08. 30. - Received: 30. 08. 2021. - https://doi.org/10.14382/epitoanyag-jsbcm.2021.9
Hadeel Mahmood MUSSA

Is a university postgraduate student in Mustansirivah University, Iraq. She is studying for a master degree in Engineering of Materials.

Tawfeeq Wasmi M. SALIH Is a university teacher in Mustansiriyah University, Iraq. He has a Ph.D. in Mechanical Engineering. He teaches Insulation Materials and Heat Transfer and has many researches in renewable energies and energy efficient buildings.

\title{
Abstract
}

The aim of this study is evaluating the thermal performance of wood plastic composites (WPCs) as insulation panels depending on the values of thermal conductivity (k). Three types of wood flour taken from (pine, oak and walnut) trees with concentrations (10, 20, $30 \%)$, and two types of thermoplastics; high density polyethylene (HDPE) and polypropylene (PP), have been selected for the evaluation. Theoretical work uses mathematical relations in the calculation of thermal conductivity of WPCs. Experimental work includes the manufacturing of the specimens, the measurements of k-values. The results show that the increasing in wood content leads to a reduction in k-values for WPCs by $6-8.5 \%$ for each $10 \%$ addition of wood. The k-values of WPCs tend to increase, when temperatures rise from $25-75^{\circ} \mathrm{C}$, by $20-25 \%$ for HDPE-wood composites, and by $15-20 \%$ for PP-wood composites. Furthermore, $10 \%$ of water content will increase the k-value by $10-20 \%$.

Keywords: wood, plastic, composite, thermal conductivity, insulation

Kulcsszavak: fa, mủanyag, kompozit, hôvezetố képesség, szigetelés

\section{Introduction}

There are many technical solutions to decrease energy consumption and reduce greenhouse emissions, which is necessary also because of the need for the energy balance improving [1]. Thermal insulation is an essential part in the residential building to prevent heat transfer between outside and inside. Most of insulation materials are synthetic materials which consume extra sources of raw materials, and spend a lot of money and effort. Recently, many investigations have been developed to invest the natural materials or recycled materials. Wood plastic composites (WPCs) are relatively new family of composites and environmentally friend materials, where they can be manufactured from recycled plastics and waste woods. The wooden materials are usually: wood fiber, flour fiber, kenaf hemp and sisal. While, the plastics are usually: polyethylene (PE), polypropylene (PP), polyvinyl chloride (PVC) [2]. Wood contents in WPCs may reach $50 \%$ of the composition. The wood and thermoplastics are usually compounded above the melting temperature of the thermoplastic polymers and then further processed to make various products. WPC can be manufactured in a variety of shapes and sizes, and with different surface textures depending on the processing method [3]. Factors attributes to mechanical and thermal properties of WPCs depend on [4]: wood content, type of polymer, type of additives and processing temperature. Studies conducted in PWCs show that the presence of wood contents increases the thermal properties, i.e. thermal resistance [5]. On the other hand, the mechanical properties, i.e. tensile strengths, decrease with the increasing of wood fibers for a certain range [6].

Researchers have been looking for the development of plastics with natural wooden materials as reinforcement.
In this context, wood is usually used as flour or fiber in the composition of composite material. Several promising studies [7-24] have taken place in the evaluation of thermal properties of wood plastic composites (WPCs), for several wood types, wood contents, and polymer types as well as additives contents. Most of the studies were experimental investigations, while some others were theoretical and numerical studies or models. The major outcome of the previous works, which related to thermal properties, had focused on the thermal stability of WPC material or the variation in phase change zone and the corresponding melting point, temperature of crystallization and glass transition temperature. Less concentration had taken place for the effect of wood content on the thermal conductivity. Hence, the present study focuses on the thermal conductivity as a preferable parameter in thermal resistance calculation. The present study includes both: theoretical and experimental works. The plan suggested three types of wood flour in different concentrations (10, 20 and $30 \%)$ with two types of thermoplastics, high density polyethylene (HDPE) and polypropylene (PP).

\section{Theoretical analysis}

The coefficient of thermal conductivity is the most important property of any material which indicates whether it is an insulator or not. Material with relatively low thermal conductivity, less than $0.2 \mathrm{~W} / \mathrm{m} . \mathrm{K}$, consider as a thermal insulator [25]. The reciprocal of thermal conductivity called thermal resistivity, which is a measure of material resistance to the heat transfer. The other thermal properties are: heat reflectivity, heat capacity, coefficient of thermal expansion, thermal stability and phase-change points. 
Although several theoretical works have been conducted to determine the thermal conductivity of composite materials, there is still some inaccuracy in the predicted values due to several important parameters like: operational conditions (temperature and water content), particle features (size and distribution) as well as interface quality (adhesion). For this reason, some of these effects will be discussed through numerical simulations. The effective thermal conductivity of a composite material $\mathrm{k}$ depends on the thermal conductivities of both: the reinforcement $\mathrm{kr}$ and the matrix $\mathrm{km}$, as well as concentration $\phi$ of each material. The simplest model assumes that the particles are placed in series manner with respect to the heat flow direction. This gives [26];

$k=k_{r} \emptyset_{r}+k_{m} \emptyset_{m}$

The coefficient of thermal conductivity mainly depends on: temperature, water content and some other thermo-physical properties of the material [27]. The thermal conductivity is measured in $\mathrm{W} / \mathrm{m} . \mathrm{K}$. In general, the material with a small $\mathrm{k}$-value is a good thermal insulator; on the other hand, the material with a large $\mathrm{k}$-value is a good heat conductor.

\subsection{Temperature rise effect}

In the case of solid materials, the variation of thermal conductivity due to the change in medium temperature predominantly depends on electronic effect. The coefficient of thermal conductivity is affected by heat transport characteristics, where the microstructure of molecules affects the heat transfer. Thermal conductivity is proportional to the pore size; smaller pores will lead to lower heat conductivity [28].

In general, as temperature increases, both number of free electrons and lattice vibrations increase. Thus the thermal conductivity of the material is expected to increase. Many studies have shown that thermal conductivity of wooden materials increases with the temperature rise for a certain range, as shown in Fig. 1 [29].

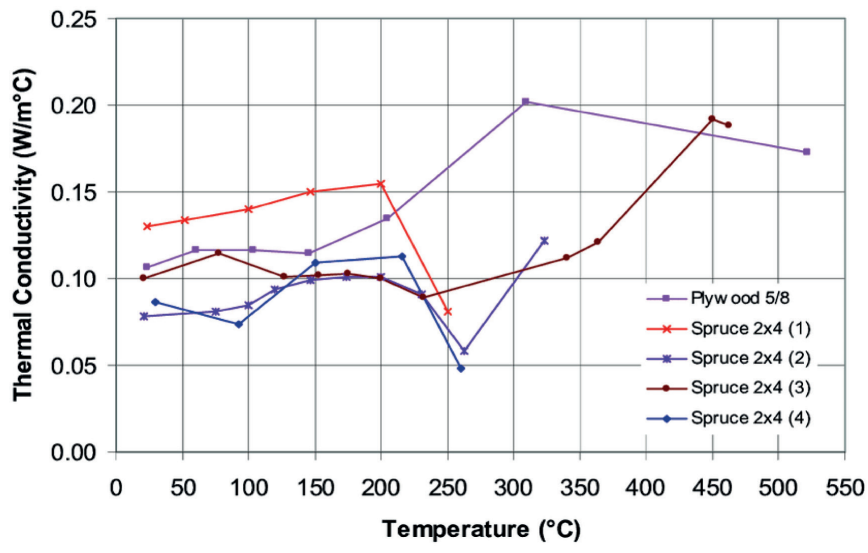

Fig. 1 Variation of thermal conductivity with the temperature for some wooden materials [29]

1. ábra A hövezető képesség változása a hömérséklet függvényében különbözö faanyagok esetében [29]

Prisco U. (2014) [14] has shown that, in wooden materials, the thermal conductivity has general linear increasing as temperature increases before degradations, as following;

$k=k_{o}+1.9 \times 10^{-4} T$
Where ko refers to the initial k-value for the selected wood in the study in a limitation of temperature not exceeds $80^{\circ} \mathrm{C}$.

Heat conduction in polymers is considered as the propagation of anharmonic elastic waves through a continuum. The temperature dependent term is interpreted as the intrinsic thermal conductivity due to the Umklapp process (an anharmonic phonon-phonon scattering process), and the temperature independent term as conductivities due to the collective contribution of all point defect scattering terms. The conductivity decreases with temperature increase because "Anharmonic Umklapp" process becomes more frequent, and hence the phonon mean free path decreases [30]. Many recent investigations [30-32] indicated that, for crystalline polymeric materials, the thermal conductivity has reciprocating relation with respect to the temperature rise. The direct effect of temperature rise on the thermal conductivity of polymers is studied efficiently in reference [33], where the study presented the behavior of some polymers, as shown in Fig. 2. It can be concluded, from these studies, that the relationship between the thermal conductivity and the temperature may have the simple linear interpolation formula:

$k=k_{o}-m T$

Where, ko is the reference $\mathrm{k}$-value at standard conditions. While, $\mathrm{m}$ is the index of variation and it has different values from polymer to another.
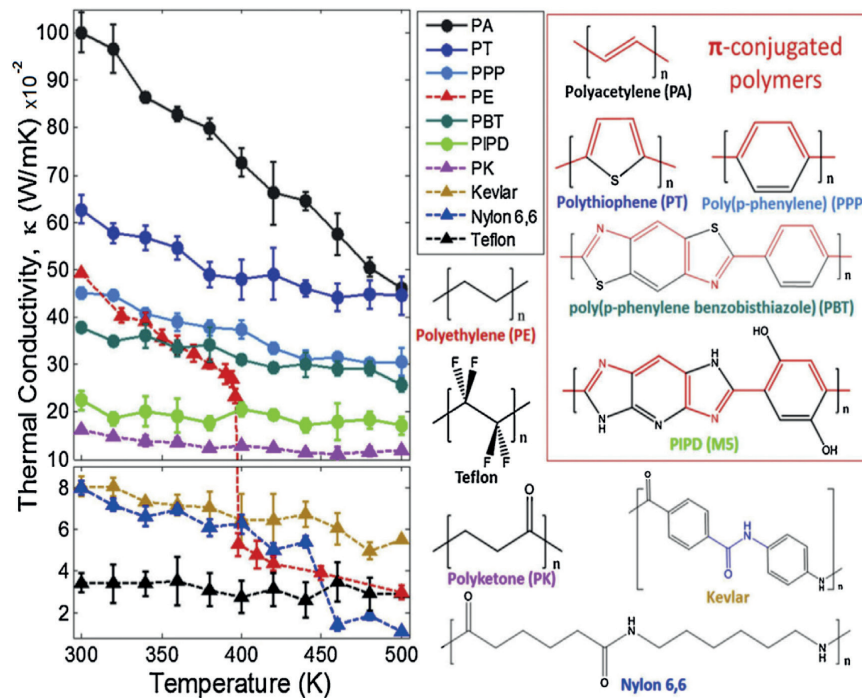

Fig. 2 Variation of thermal conductivity with the temperature for some polymers [33]

2. ábra A hővezetö képesség változása a hömérséklet függvényében különböző polimerek esetében [33]

\subsection{Water content effect}

In humid conditions, materials absorb moisture from the air, and that causes to crack, less resistance and failure [34]. When material absorbs moisture, heat begins to leak. It is noticed that the increasing of water content increases the density of the material, thus the thermal conductivity. This behavior has been extracted from many investigations [35-40]. A study conducted by Goss W. and Miller R. (1992) [39] to investigate the effect of water content on the thermal conductivity of wood has proposed the following formula; 
$k=k_{o}+0.004 w$

Where ko refers to the initial $\mathrm{k}$-value for the selected wood in the study, while $\mathrm{w}$ is the water content up to $20 \%$ limit. This behavior is in line with a study carried out by Kawasaki T. and Kawai S. (2006) [40], where the increasing in the value of thermal conductivity for ply sandwich wood (PSW) with density range between $100-800 \mathrm{~kg} / \mathrm{m}^{3}$ was about $10-25 \%$ for a water content ranged between $5-10 \%$.

\section{Experimental work}

In the current study, composite materials made of recycled wood and plastic, known as wood-plastic composites (WPCs), have proposed as thermal insulation materials. For this purpose, an experimental work has been done to manufacture and evaluate the thermal performance of WPCs as thermal insulations. The work includes collecting a group of materials (some woods and some plastics) and manufacturing a set of specimens with different mixing ratios, as well as different conditions. The tests include measuring the coefficient of thermal conductivity in room temperature and when temperature rises for certain ranges as well as water content.

\subsection{Materials}

A bunch of dried wood samples has been collected from the local market and this includes: Pine Wood (PW), Oak Wood (OW) and Walnut Wood (WW). It is worth noting that these samples of wood must be cut, spread, dried and grinded in order to obtain pure wood flour, as shown in Fig. 3.

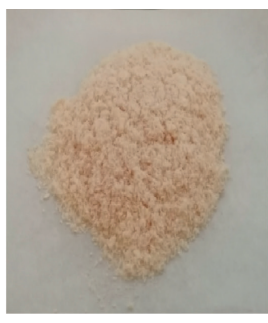

Pine

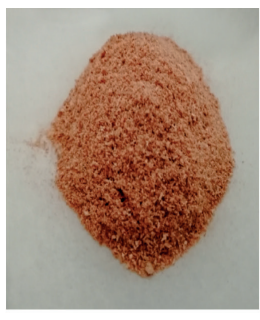

Oak

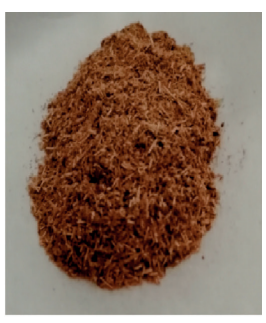

Walnut
Fig. 3 Wood flour used in the study

3. ábra A tanulmányban használt fa ôrlemények

Initially, some solid samples of the woods had taken to calculate their densities, by measuring both: volume (by ruler) and mass (by weight scale). These values have been compared with average values that taken from reliable sources [41-43], as shown in Table 1. The comparison indicates a slight percentage of variation and that is mostly due to the difference in the features of wood.

\begin{tabular}{ccc} 
Wood type & $\begin{array}{c}\text { Density }\left(\mathrm{g} / \mathrm{cm}^{3}\right) \\
\text { as solid }[41-43]\end{array}$ & $\begin{array}{c}\% \text { Variation } \\
\text { to the type used }\end{array}$ \\
\hline Pine Wood (PW) & 0.45 & $+11 \%$ \\
\hline Oak Wood $(\mathrm{OW})$ & 0.70 & $+6 \%$ \\
\hline Walnut Wood $(\mathrm{WW})$ & 0.78 & $+5 \%$ \\
Table 1 Densities of woods & \\
1. táblázat A vizsgált faanyagok sürüsége
\end{tabular}

Other thermo-physical properties such as: specific heat, thermal conductivity and degradation temperature, are shown in Table 2 .

\begin{tabular}{cccc} 
Wood type & $\begin{array}{c}\text { Specific heat } \\
\text { (J/kg.K) }\end{array}$ & $\begin{array}{c}\text { Thermal conductivity } \\
(\mathbf{W} / \mathbf{m} \cdot \mathbf{K})\end{array}$ & $\begin{array}{c}\text { Degradation } \\
\text { Temp. }\left({ }^{\circ} \mathbf{C}\right)\end{array}$ \\
\hline $\begin{array}{c}\text { Pine Wood } \\
\text { (PW) }\end{array}$ & $1500-1800$ & $0.12-0.13$ & $200-235$ \\
\hline $\begin{array}{c}\text { Oak Wood } \\
\text { (OW) }\end{array}$ & $2000-2400$ & $0.14-0.16$ & $200-220$ \\
\hline $\begin{array}{c}\text { Walnut Wood } \\
\text { (WW) }\end{array}$ & $2000-2400$ & $0.17-0.19$ & $200-225$ \\
\hline
\end{tabular}

Table 2 Some properties of woods from references [43-45]

2. táblázat A vizsgált faanyagok fontosabb tulajdonságai az irodalom alapján [43-45]

Thermoplastics that have melting point less than wood degradation temperature are commonly used with WPCs. Two types of thermoplastic materials have been purchased from the local market, which are: High Density Polyethylene (HDPE) and Polypropylene (PP). In order to ensure sufficient woodplastic composites, granular raw materials of these plastics have been used, as shown in Fig. 4.

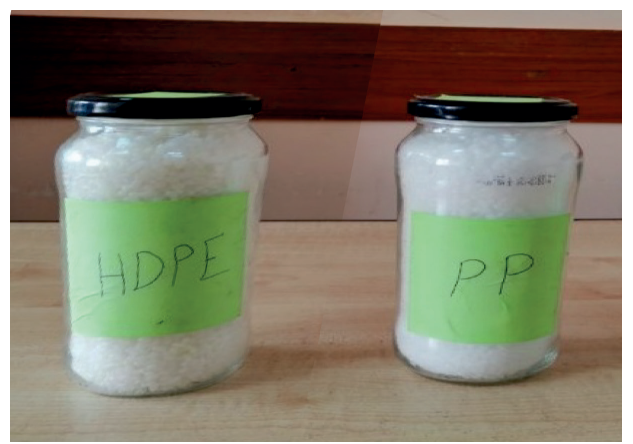

Fig. 4 Plastic grains used in the study

4. ábra A vizsgálat müanyag szemcsék

Initially, some solid pieces of these types of plastics were formed using the oven with certain dimensions, where their volumes and weights have been measured to calculate the density, as shown in Table 3 . The average values that extracted from references [46-48] indicated an acceptance percentage of variation due to the difference in the features of plastics. Other thermo-physical properties, would be useful in the study, are shown in Table 4.

\begin{tabular}{ccc} 
Plastic type & $\begin{array}{c}\text { Density }\left(\mathrm{g} / \mathrm{cm}^{3}\right) \\
\text { as solid }[46-48]\end{array}$ & $\begin{array}{c}\% \text { Variation to } \\
\text { the type used }\end{array}$ \\
\hline High density polyethylene (HDPE) & 0.95 & $+1 \%$ \\
\hline Polypropylene (PP) & 0.90 & $+2 \%$
\end{tabular}

Table 3 Densities of plastics

3. táblázat A vizsgált müanyagok sürüsége

\begin{tabular}{cccc} 
Plastic type & $\begin{array}{c}\text { Specific } \\
\text { heat } \\
(\mathbf{J} / \mathbf{k g} \cdot \mathbf{K})\end{array}$ & $\begin{array}{c}\text { Thermal } \\
\text { conductivity } \\
\text { (W/m.K) }\end{array}$ & $\begin{array}{c}\text { Melting } \\
\text { point } \\
\left({ }^{\circ} \mathbf{C}\right)\end{array}$ \\
\hline $\begin{array}{c}\text { High density polyethylene } \\
\text { (HDPE) }\end{array}$ & $2000-2500$ & $0.44-0.48$ & $140-160$ \\
\hline Polypropylene (PP) & $1500-2000$ & $0.19-0.22$ & $160-180$
\end{tabular}

Table 4 Some properties of plastics from references [49-53]

4. táblázat A vizsgált müanyagok fontosabb tulajdonságai az irodalom alapján [49-53] 
The variation in the thermo-physical properties of polymers is attributed to the features of type used which may be commercial or in accordance to a standard code. However, it is easy to recognize a certain type of polymer by comparing the values of several properties where there is similarity in the whole type used.

\subsection{Manufacturing}

The experimental work included manufacturing several specimens using different compositions of wood and plastic at different conditions. The work has conducted at Chemical Lab in Materials Engineering Department, Mustansiriyah University. Several devices and instruments have been used like, oven, thermometer, weight scale and molds. Some tools and auxiliaries have been used as well.

The majority of WPC researches suggested considering an amount of wood less than that of plastic to ensure sufficient bonding between the two components, thus the current study assumed a wood content not more than $30 \%$ of the total weight. The wood was oven dried at $80{ }^{\circ} \mathrm{C}$ for 2 hours before processing to remove the moisture content (No more than 5\%). However, WPC specimens prepared in the current study with their mixing ratios are shown in Table 5.

\begin{tabular}{ccc}
$\begin{array}{c}\text { WPC type } \\
\text { HDPE }\end{array}$ & Mixing ratio (\%) & No. of specimens \\
\hline HDPE-PW & $90-10,80-20,70-30$ & 2 \\
\hline HDPE-OW & $90-10,80-20,70-30$ & 6 \\
\hline HDPE-WW & $90-10,80-20,70-30$ & 6 \\
\hline PP & 100 & 6 \\
\hline PP-PW & $90-10,80-20,70-30$ & 2 \\
\hline PP-OW & $90-10,80-20,70-30$ & 6 \\
\hline PP-WW & $90-10,80-20,70-30$ & 6 \\
\hline
\end{tabular}

Table 5 Mixing ratios of WPC specimens used in the study

5. táblázat A vizsgálatban használt WPC minták keverési arányai

For each WPC, two samples have manufactured for thermal conductivity test. Furthermore, four specimens have manufactured for temperature rise tests, and four specimens for water content tests. Besides that, three specimens have manufactured for pure wood evaluation. Thus, the total quantity reached to (51) specimens.

The desired quantities for each specimen components have weighted and combined in well mixing procedure, where two stages have proposed to ensure homogenous product as much as possible. In the first stage, some of the wood flour has mixed with the plastic grains in a bowl and then pour the mixture into a sheet of parchment paper to insert it easily to the oven for a period of time till the melting point. After that, the second stage of mixing is beginning by spreading the rest of the wood flour into the melted plastic and rolling it carefully. The oven used in the study is assigned for polymer melt-works which has the brand Jrad, with Italian thermostat operates up to $250{ }^{\circ} \mathrm{C}$, as shown in Fig. 5.

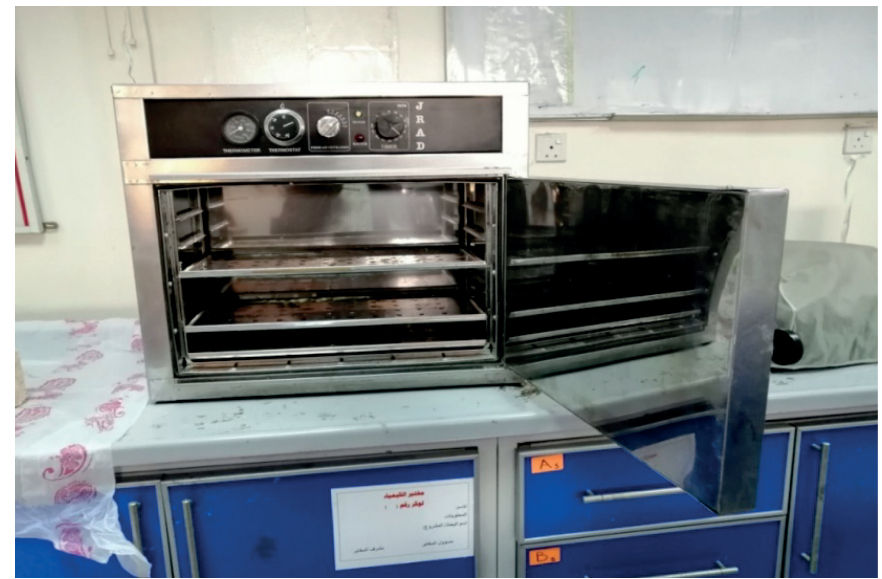

Fig. 5 Oven used in the study

5. ábra A vizsgálatokhoz használt kemence

The period that the plastic grains spent in the oven to get melting, starting from room temperature, was ranged between 20-25 minutes at a constant rate of heat $\left(10^{\circ} \mathrm{C} / \mathrm{min}\right)$. After that, the molten plastic-wood paste has ejected from the oven and inserted into the mold which has the dimensions: $5 \times 5 \times 1 \mathrm{~cm}^{3}$. The paste of wood-plastic should be pressed in the mold using an appropriate cap which holds a weight of $2 \mathrm{~kg}$ and for a period of 10 minutes. The advantage of pressing is to strengthen the produced specimen during heat transfer process in the product to ensure sufficient WPC formation. Parchment paper or aluminium foil could be used in the base of the mold to extract the specimens easily. Finally, the specimens should be exposed to the still air for a period of 5 minutes for cooling.

Measurements of thermal conductivity require specimens have circular shapes of $42 \mathrm{~mm}$ diameter. Therefore, the manufactured specimens should be cut using a circular holesaw. The final shapes of specimens are shown in Fig. 6.
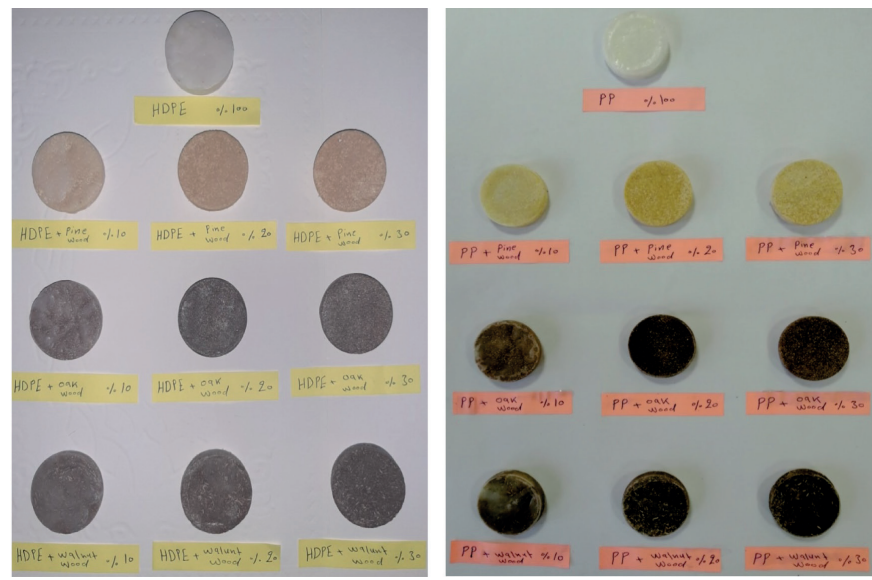

Fig. 6 Final shapes of WPC specimens (left: HDPE-wood; right: PP-wood) 6. ábra A WPC minták végső formája (balra: HDPE-fa; jobbra: PP-fa)

\subsection{Measurements of thermal conductivity}

The measurements of thermal conductivity for the specimens have conducted at the laboratory of Materials Research Department in Ministry of Science and Technology (MOST) according to ASTM C518 - 04, using Lee's disc apparatus, as shown in Fig. 7. 


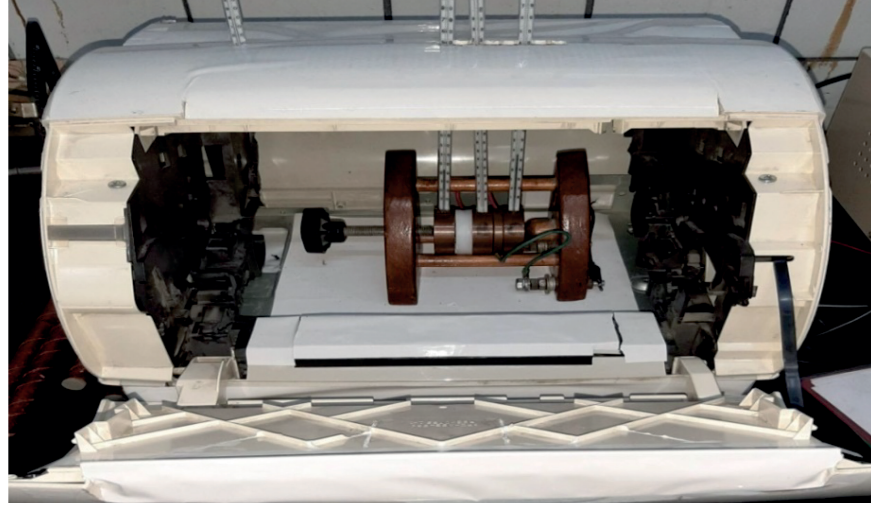

Fig. 7 Specimen is placed in the apparatus between hot and cold discs 7. ábra A készülékbe helyezett minták meleg és hideg lemezek között

The device consists of a chamber and a reader. The chamber has an electric heater, and there is a group of discs where the specimen should be placed between the hot and cold discs. The chamber has sufficient thermal insulation. The electric circuit was switched on until the equilibrium condition is reached. The reader recorded the temperatures across the specimen using sensors connected to a thermometer. The recorded values have compensated in a special equation approved for this device.

Since the produced WPC is assigned for residential applications (thermal insulation), thus the surface temperature on the hot side was limited not to exceed $80^{\circ} \mathrm{C}$. It is important to refer here, that the thermal conductivity of pure solid wood specimens of (pine, oak and walnut) has measured as well in the same procedure. Furthermore, extra specimens of HDPEPW and PP-PW, 10\%, 20\% and 30\% wood content, have been selected for temperature rise tests. Moreover, four specimens of HDPE-PW and PP-PW, 30\% wood content, have been selected for water content tests at $10 \%$ and $20 \%$ water content. For this purpose, the wood flour should be put in the water for certain period of time (several days) to insure increasing in wood mass due to water content by $10 \%$ or $20 \%$.

\section{Results and discussion}

The thermal conductivity (k-value) is the property which indicates whether the material is a good insulator or not. The thermal conductivity of WPCs has been investigated in three situations; standard conditions, temperature rise effect and water content effect.

\subsection{Standard k-values of WPCs}

In general, the increasing in wood content leads to a reduction in k-value for WPC material because k-value of wood is less than that of polymer, thus the overall $\mathrm{k}$-value of the composite tends to decrease. This decreasing was linear, as shown in Figs. 8-13. For HDPE-wood composites, it is noticed that there is a significant reduction in $\mathrm{k}$-value when pine wood is used, due to the low $\mathrm{k}$-value for pine wood $(\mathrm{k}=0.12 \mathrm{~W} / \mathrm{m} . \mathrm{K})$ in compare to oak wood $(\mathrm{k}=0.15 \mathrm{~W} / \mathrm{m} . \mathrm{K})$ and walnut $\operatorname{wood}(\mathrm{k}=0.17 \mathrm{~W} / \mathrm{m} . \mathrm{K})$. Theoretically, the reduction in k-value of HDPE-wood composite for every $10 \%$ addition of wood was about $8.5 \%$ when pine wood is used. On the other hand, it was $6.8 \%$ when oak wood is used. Furthermore, the using of walnut wood gave $6.2 \%$ reduction in $\mathrm{k}$-value. This amount of increasing is going to be double when there is $20 \%$ addition of wood, or triple when there is $30 \%$ addition of wood. For PP-wood composites, the reduction in the k-value by the increasing of wood content was small (3-4\%) due to the fact that $\mathrm{k}$-value of pure PP raw material is basically low $(\mathrm{k}=0.22 \mathrm{~W} / \mathrm{m} . \mathrm{K})$ compared to that of HDPE $(\mathrm{k}=0.48 \mathrm{~W} / \mathrm{m} . \mathrm{K})$. Hence, the addition of wood to PP has less reduction in $\mathrm{k}$-value. So, it is concluded that the technique of WPC is useful with plastics that have relatively high $\mathrm{k}$-values (more than $0.3 \mathrm{~W} / \mathrm{m} . \mathrm{K}$ ) such as; HDPE, LDPE and PA in order to get clear benefits of wood addition, thus reasonable results. The experimental k-values of HDPE-wood composite were lower than that calculated theoretically by a range of $1-6 \%$, while for PP-wood composites they were higher by $1 \%$. The difference between experimental and theoretical values is due to the inaccuracy of mathematical equation used, since it is a simple relation, as well as a percentage of error in experimental readings. However, the range of difference was slight.

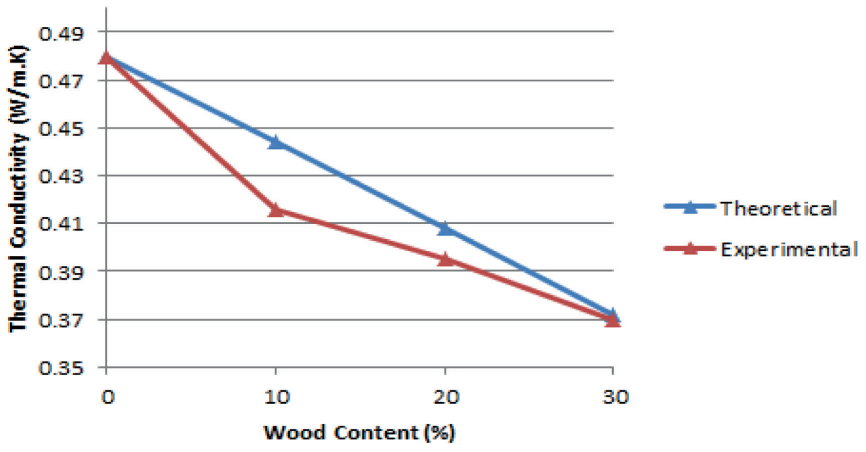

Fig. 8 Standard $k$-values for HDPE-PW

8. ábra A HDPE-PW szabványos k-értékei

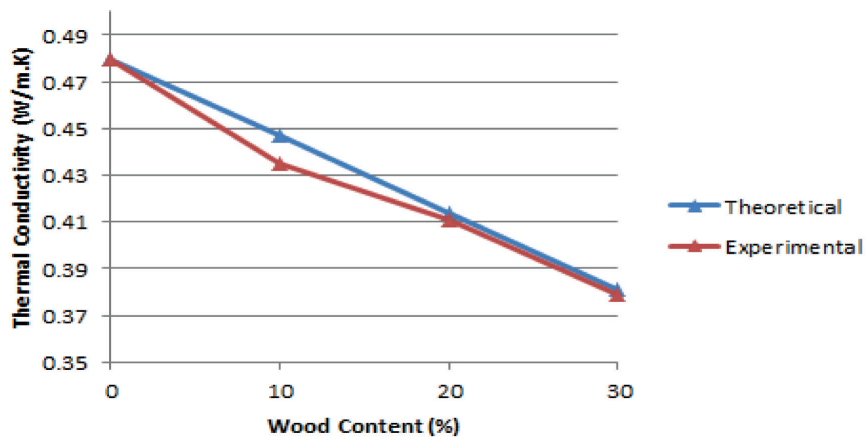

Fig. 9 Standard $k$-values for HDPE-OW

9. ábra A HDPE-OW szabványos k-értékei

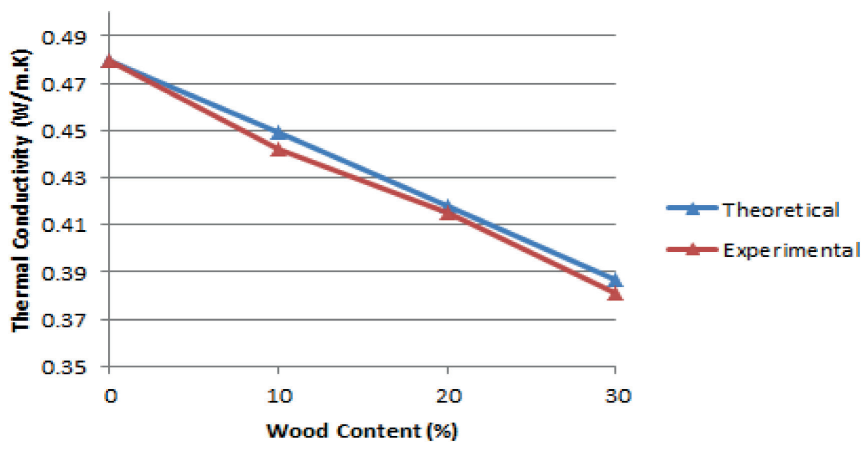

Fig. 10 Standard $k$-values for HDPE-WW 10. ábra A HDPE-WW szabványos k-értéke 


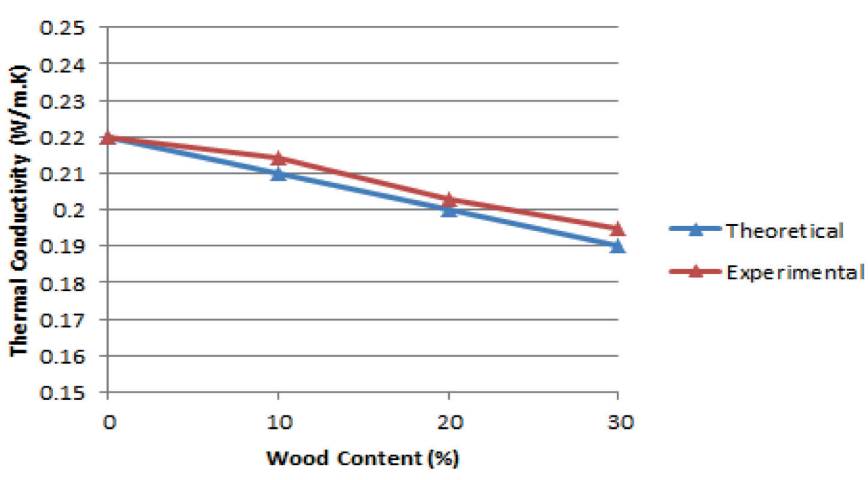

Fig. 11 Standard $k$-values for PP-PW

11. ábra A PP-PW szabványos k-értékei

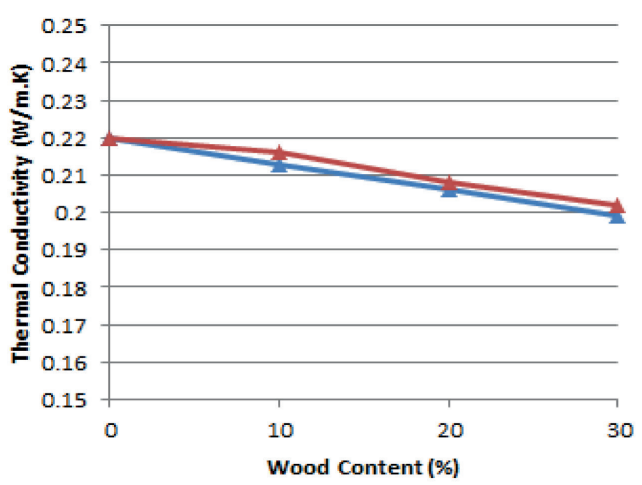

Fig. 12 Standard $k$-values for PP-OW

12. ábra A PP-OW szabványos k-értékei

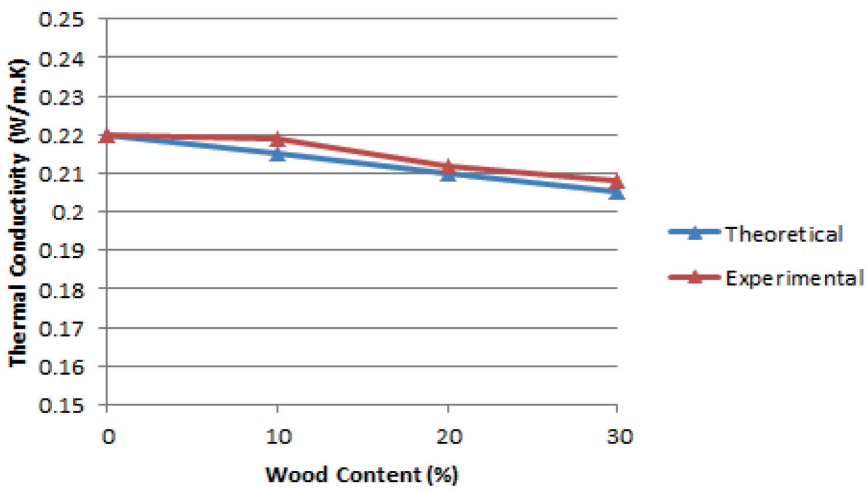

Fig. 13 Standard $k$-values for PP-WW

13. ábra A PP-WW szabványos k-értékei

\subsection{Effect of temperature rise on $\mathrm{k}$-valves}

As mentioned theoretically, that the temperature rise has a negative impact on $\mathrm{k}$-value of the wood and a positive impact on $\mathrm{k}$-value of the polymer. Where $\mathrm{k}$-value of wood increases proportionally when temperature rises for a certain range. On the other hand, k-value of polymer has a reciprocating relationship with temperature rise. Since the majority of the composition of WPC is polymer, hence the k-value of WPC tends to decrease with temperature rise. This theoretical behavior can be noticed clearly, as shown in Figs. 14-19, for HDPE-PW composites and PP-PW composites, where the temperature range was not exceeded $75^{\circ} \mathrm{C}$. The experimental results gave a contradictory behavior for the effect of temperature rise on $\mathrm{k}$-value of WPCs. Where, the k-value of WPC tends to increase with temperature rise due to the presence of $\mathrm{H}_{2} \mathrm{O}$ which evaporated from the wood and filled the cavities, where $\mathrm{k}_{\text {vapor }}>\mathrm{k}_{\text {air }}$, thus increasing in the overall $\mathrm{k}$-value of the composite material without focusing on the side of the majority of the polymer in the composition of WPC. So, it is very important to modify the mathematical equation that describes the k-value of WPC by adding the temperature rise effect in the consideration. Experimentally, the temperature rise from $25-75^{\circ} \mathrm{C}$ leads to an increase in $\mathrm{k}$-value by $20-25 \%$ for HDPE-PW composites, and by 15-20\% for PP-PW composites. These percentages are effective and may increase further if extra wood content is included, thus it is recommended (in high temperatures) to use relatively low amount of wood comparing to the polymer in the composition of WPCs, if there is no stabilizers or coupling agents used.

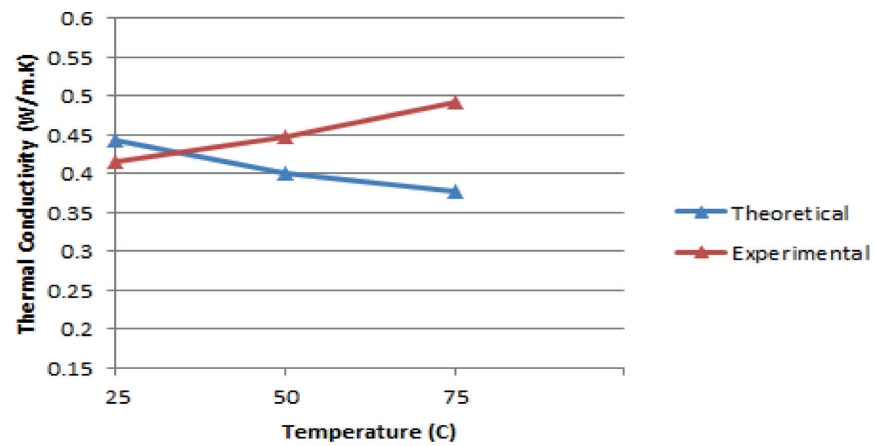

Fig. 14 Effect of temperature on $k$-values for HDPE-10\%PW

14. ábra A hőmérséklet hatása a k-értékére HDPE-10\%PW esetén

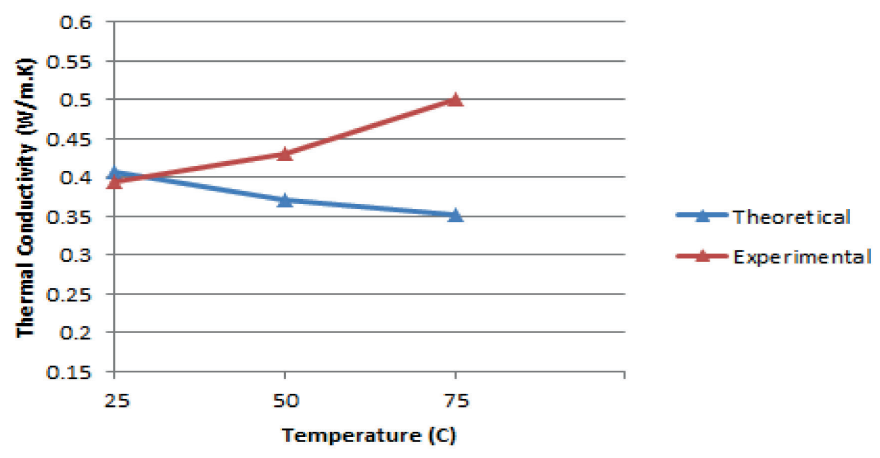

Fig. 15 Effect of temperature on $k$-values for HDPE-20\%PW 15. ábra A hömérséklet hatása a k-értékére HDPE-20\%PW esetén

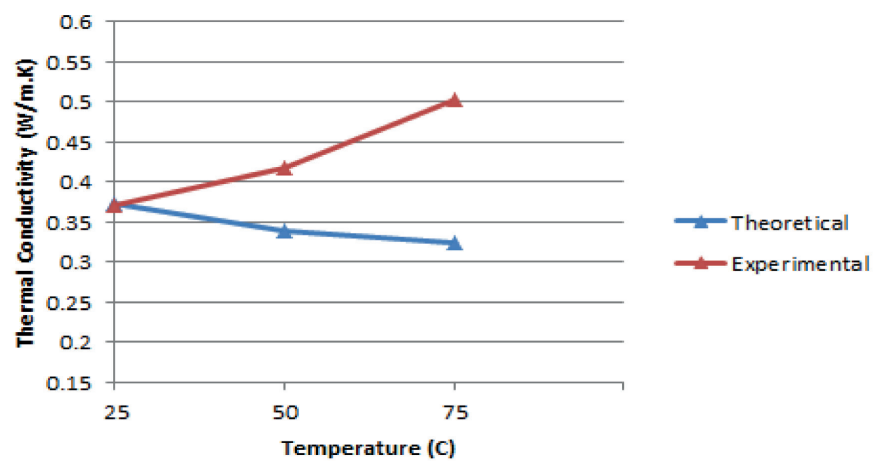

Fig. 16 Effect of temperature on $k$-values for HDPE-30\%PW 16. ábra A hömérséklet hatása a k-értékére HDPE-30\%PW esetén 


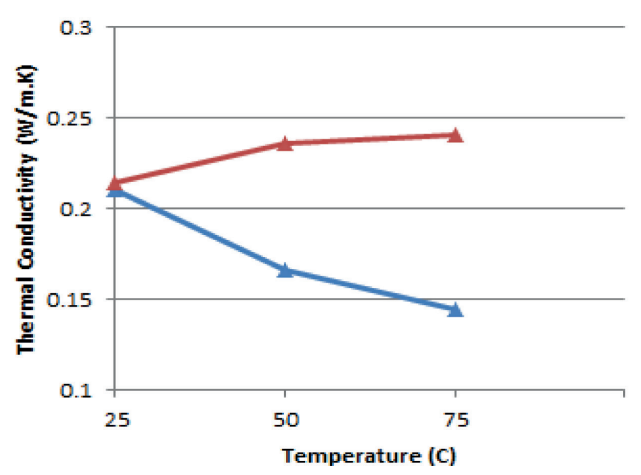

Fig. 17 Effect of temperature on $k$-values for PP-10\%PW 17. ábra A hömérséklet hatása a k-értékére PP-10\%PW esetén

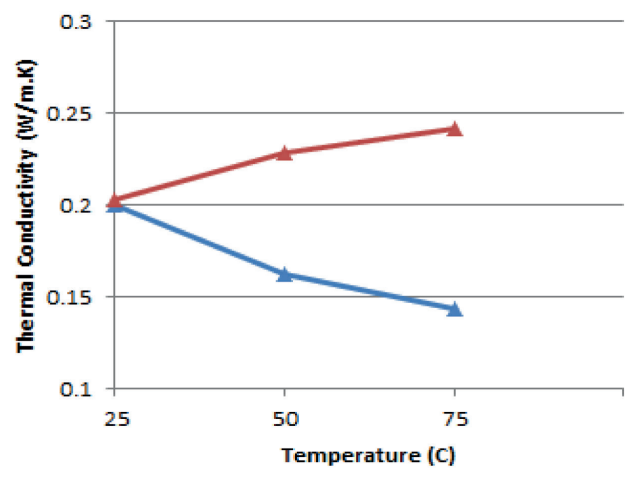

Fig. 18 Effect of temperature on $k$-values for PP-20\%PW 18. ábra A hömérséklet hatása a k-értékére PP-20\%PW esetén

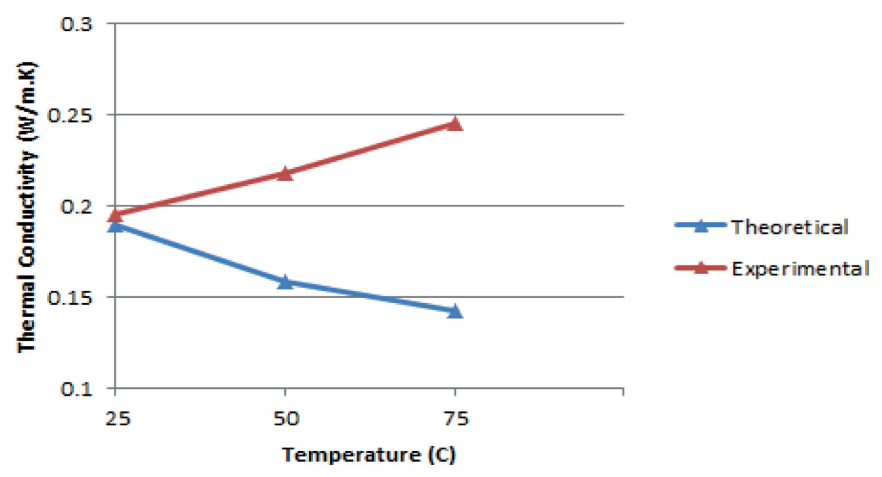

Fig. 19 Effect of temperature on $k$-values for PP-30\%PW 19. ábra A hömérséklet hatása a k-értékére PP-30\%PW esetén

\subsection{Effect of water content on k-values}

The presence of water content in the wood will increase its $\mathrm{k}$-value, because water molecules will fill the cavities, and since $\mathrm{k}_{\text {water }}>\mathrm{k}_{\text {air }}$ that means increasing in the overall $\mathrm{k}$-value of the composite material. In this test, readings were taken at different percentages of water content $(5,10,20 \%)$ in the pine wood mixed with either HDPE or PP. It is clearly that the increasing in the water content leads to increase the $\mathrm{k}$-value of WPCs, as shown in Figs. 20 and 21. The increase in k-value of HDPE-PW composite was about $15-20 \%$ for each $10 \%$ addition of water content, and it was about $10-15 \%$ for PPPW composite. The experimental results were relatively higher than the theoretical due to the fact that wet wood flour has spread over the entire WPC composition thus impacted more on the k-values. As a result, it is concluded that water content is undesired parameter because it has a negative impact on the $\mathrm{k}$-value of WPC insulation panel.

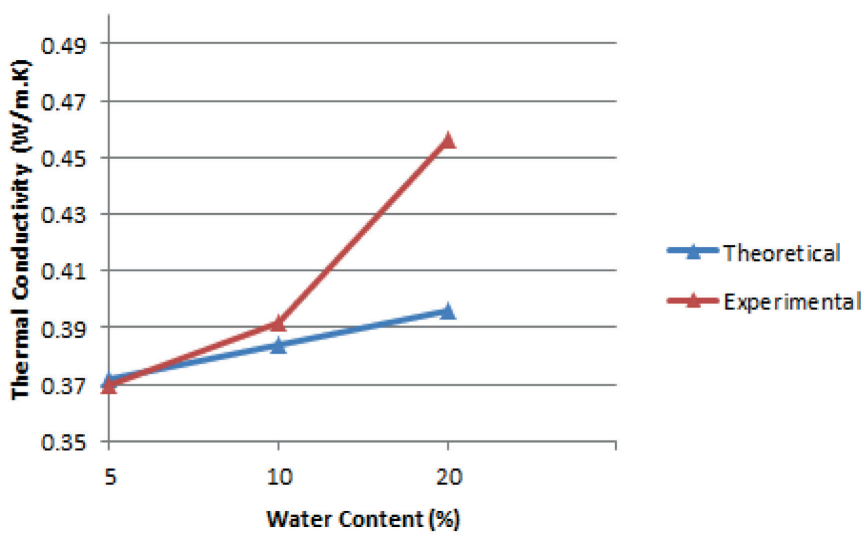

Fig. 20 Effect of water content on $k$-values for HDPE-30\%PW 20. ábra A viztartalom hatása a k-értékére HDPE-30\%PW esetén

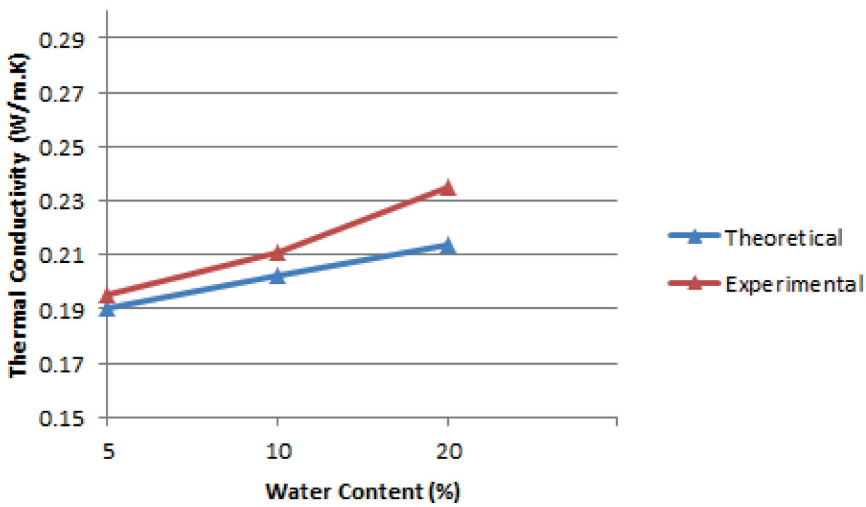

Fig. 21 Effect of water content on $k$-values for PP-30\%PW 21. ábra A viztartalom hatása a k-értékére PP-30\%PW esetén

\section{Conclusions}

Wood plastic composites (WPCs) that manufactured from waste wood and recycled plastics have possessed some advantages since they are renewable and environmentally fried, and present some desired thermo-physical properties. They are easy in manufacturing and can be produced as thermal insulation panels with a wide range of applications in the field of constructions, facilities and equipment. However, some specific points could be concluded from the recent study as following:

- The increasing in wood content leads to a decrease in $\mathrm{k}$-value for WPC material because k-value of wood is less than that of polymer.

- The decrease in k-value of WPC was $6-8.5 \%$ for each $10 \%$ addition of wood.

- The k-value of WPC tends to increase with temperature rise due to the presence of $\mathrm{H} 2 \mathrm{O}$ which evaporated from the wood and filled the cavities, thus increasing in the overall k-value of the composite material.

- The temperature rise from $25-75^{\circ} \mathrm{C}$ leads to an increase in k-value by $20-25 \%$ for HDPE-PW composites, and by $15-20 \%$ for PP-PW composites. These percentages are effective and may increase further if extra wood content is included. 
- It is important to modify the mathematical equation that describes the k-value of WPC by adding the temperature rise effect in the consideration.

- The presence of water content in the wood will increase its $\mathrm{k}$-value, because water molecules will fill the cavities, and since $\mathrm{k}_{\text {water }}>\mathrm{k}_{\text {air }}$.

- The increase in $\mathrm{k}$-value due to water content in HDPE-PW composite was about $15-20 \%$ for each $10 \%$ addition of water content, and it was about $10-15 \%$ for PP-PW composite.

\section{Acknowledgments}

Authors are grateful to all support given by College of Engineering, Mustansiriyah University for academically support.

\section{References}

[1] Komlós Ferenc, "Heat insulation and heat pump systems", Építőanyag Journal of Silicate Based and Composite Materials, Vol. 60, No. 3, P.78-86, 2008. https://dx.doi.org/10.14382/epitoanyag-jsbcm.2008.14

[2] Tabarsa T., Khanjanzadeh H., Pirayesh H., "Manufacturing of woodplastic composite from completely recycled materials", Key Engineering Materials, Vols. 471-472, Pages 62-66, 2011, https://doi.org/10.4028/www.scientific.net/KEM.471-472.62

[3] Adam T., Vikram Y., Karl R., David H., "Wood plastic composites - a primer", Washington State University, PB 1779, 2010

[4] Andre S., "Wood plastic composites (WPCs) as an alternative to solid lumber", Thesis, University of British Columbia, 2011

[5] João B., Carlos M., Fernando C., Raul F., "Influence of different thermoplastic polymer/wood ratios on the mechanical and thermal properties of composite materials", Procedia Engineering, 200, 480-486, 2017, https://doi.org/10.1016/j.proeng.2017.07.067

[6] Wolcott M., Englund K., "A technology review of wood plastic composites", 33rd International Particleboard/Composite Materials Symposium, Washington State University, Pages 103-110, 1999

[7] John Z., Qinglin W., Ioan I., "Surface and interfacial characterization of wood-PVC composites: Thermal and dynamic mechanical properties", Wood and Fiber Science, 36(4), Pages 500-510, 2004

[8] Alireza Kaboorani, "Effects of formulation design on thermal properties of wood/thermoplastic composites", Journal of Composite Materials, Vol. 44, No. 18, Pages 2205-2215, 2010, https://doi.org/10.1177/0021998309360938

[9] Song G., Qiu-yi L., Yi-wen Z., "Experimental research on the thermal insulation and flame retardancy performance of WPC wallboard made of paper-aluminum-plastics wastes", Applied Mechanics and Materials, Volumes 34-35, Pages 1676-1680, 2010

[10] Diene N., Laurent M., Sandrine M., Lorc V., Adams T., Jean-Luc G., "Thermal and mechanical properties of polypropylene/wood-flour composites", Journal of Applied Polymer Science, Vol. 119, Pages 33213328, 2011, https://doi.org/10.1002/app.32985

[11] Thanate R., Natchayapa T., Chatree H., "Mechanical and thermal properties of oil palm wood sawdust reinforced post-consumer polyethylene composites", ScienceAsia, 38, Pages 289-294, 2012

[12] Yiqun F., Qingwen W., Xiaoyan B., Weihong W., Paul A., "Thermal and burning properties of wood flour poly (vinyl chloride) composite", J Therm Anal Calorim, 109:1577-1585, 2012, https://doi.org/10.1007/s10973-011-2071-y

[13] Karim B., Bernard R., Denis R., "Effect of temperature on the thermal conductivity of wood-plastic composites", Polymers \& Polymer Composites, Vol. 21, No. 7, 2013

[14] Prisco U., "Thermal conductivity of flat-pressed wood plastic composites at different temperatures and filler content", Sci Eng Compos Mater, 21(2), Pages 197-204, 2014
[15] Mazzanti V., Mollica F., El Kissi N., "Rheological and thermal properties of PP-based WPC", Times of polymers and composites, AIP Conference, Pages 274-277, 2014

[16] Hossain M., Shoumya N., Islam M., "Effect of types of wood on the thermal conductivities of wood saw dust particle reinforced composites", 10th International Conference on Mechanical Engineering, ICME 2013, Procedia Engineering, 90, Pages 46 - 51, 2014

[17] Rafel R., Josep P., José M., Jordi G., Francesc X., Gerard A., Pere M., "Orange wood fiber reinforced polypropylene composites: Thermal properties", Bioresources, 10(12), Pages 2156-2166, 2015

[18] Patrick Z., Elke M., Andre G., Torsten T., Antje L., "Synthesis of polyamide 6/11 copolymers and their use as matrix polymer in wood-plastic composites", Journal of Applied Polymer Science, 44155, Wiley, 2016, https://doi.org/10.1002/app.44155

[19] Alperen K., Turker G., Seyyed H., Nadir A., "Physical, mechanical and thermal properties of wood/zeolite/plastic hybrid composites", Maderas, Ciencia y tecnología, 19(3): 339 - 348, 2017

[20] Chung M., Park J., "An experimental study on the thermal performance of phase-change material and wood-plastic composites for building roofs", MDPI, Energies, 10 (195), 2017

[21] Shirley S., Leigh M., Tim G., Adrian K., "Properties of nylon-6-based composite reinforced with coconut shell particles and empty fruit bunch fibres", Plastics, Rubber and Composites, T\&F, VOL. 47, NO. 2, Pages 7786, 2018, https://doi.org/10.1080/14658011.2017.1418711

[22] Yong G., Shiliu Z., Yuxia C., Dagang L, “Thermal properties of woodplastic composites with different compositions", Materials, MDPI, 12:881, 2019

[23] Xingli Z., Jinglan Z., Ruihong W., "Thermal and mechanical behavior of wood plastic composites by addition of graphene nanoplatelets", MDPI, Polymers, 11, 1365, 2019

[24] Jawad Lamyaa Abd Alrahman, Salih, Tawfeeq Wasmi M., "An investigation into practical values of sound transmission loss across natural luffa fibers", Építőanyag - Journal of Silicate Based and Composite Materials, Vol. 72, No. 3 (2020), P. 106-109 https://doi.org/10.14382/epitoanyag-jsbcm.2020.17

[25] Tawfeeq W. Salih, "Insulation materials", Bachelor Notes, University of Mustansiriyah, 2017

[26] Idicula M., Boudenne A., Umadevi L., Ibos L., Candau Y., Thomas S., "Thermophysical properties of natural fiber reinforced polyester composites", Comp. Sci. Tech., 66 (15), Pages 2719- 2725, 2006, https://doi.org/10.1016/j.compscitech.2006.03.007

[27] Zhang Z., "Effect of temperature on rock fracture", Rock Fracture and Blasting: Theory and Applications, Elsevier, Pages 111-133, 2016

[28] Hahn W., Özişik M., "Heat conduction", 3rd Ed., Wiley, 2012

[29] Benichou N., Sultan M., Maccallum C., Hum J., "Thermal properties of wood, gypsum and insulation at elevated temperatures", IR-710, NRCCNRC, Canada, 2001

[30] Kingery W., McQuarrie M., "Thermal conductivity: I - concepts of measurement and factors affecting thermal conductivity of ceramic materials", J. Am. Ceramic Soc. 37 (2), 67, 1954

[31] Dos Santos W., De Sousa J., Gregorio R., "Thermal conductivity behaviour of polymers around glass transition and crystalline melting temperatures", Polymer Testing, 32, 987-994, Elsevier, 2013, https://doi.org/10.1016/j.polymertesting.2013.05.007

[32] Hongyu C., Valeriy G., Jian Y., Yunfeng Y., Wei L., Yan H., Libo D., Bin C., "Thermal conductivity of polymer-based composites: Fundamentals and applications", Progress in Polymer Science, Volume 59, Pages 41-85, 2016

[33] Zhang T., Wu X., Luo T., "Polymer nanofibers with outstanding thermal conductivity and thermal stability: fundamental linkage between molecular characteristics and macroscopic thermal properties", J Phys Chem C, 118:21148-59, 2014

[34] Gong B., Youping T., Yiyang Z., Ruihai L., Fuzeng Z., Zhuo X., Dong L., "Moisture absorption characteristics of silicone rubber and its effect on dielectric properties", Annual Report Conference on Electrical Insulation and Dielectric Phenomena, IEEE, 2013

[35] Shida S., Okuma M., "Dependency of thermal conductivity of wood based materials on temperature and moisture content (in Japanese), Mokuzai Gakkaishi, 26:112-117, 1980 
[36] Zheng L., Zi L, Cheng L., Chen-jun G., Zhi-cheng G., Wang L., “Test \& research of water absorption \& water permeation of composite insulator HTV silicone rubber material", Shaanxi Electric Power, Vol. 40, No. 7 , Pages. 14-18, 2012

[37] Jerman M. and Robert C., "Effect of moisture content on heat and moisture transport and storage properties of thermal insulation materials", Elsevier, Energy and Buildings 53, Pages 39-46, 2012, https://doi.org/10.1016/j.enbuild.2012.07.002

[38] Ochs F., Heidemann W. and Muller-Steinhagen H., "Effective thermal conductivity of moistened insulation materials as a function of temperature", Elsevier, International Journal of Heat and Mass Transfer, 51, Pages 539-552, 2008

[39] Goss W., Miller R., "Thermal properties of wood and wood products", Proceedings of the Thermal Performance of the Exterior Envelopes of Whole Buildings International Conference, Pages 193-203, 1992

[40] Kawasaki T., Kawai S., "Thermal insulation properties of wood-based sandwich panel for use as structural insulated walls and floors", The Japan Wood Research Society, J. Wood Sci, 52:75-83, 2006

[41] Henry M., A. Besnard, W. Asante, J. Eshun, S. Adu-Bredu, R. Valentini, M. Bernoux, L. Saint-Andre, "Wood density, phytomass variations within and among trees, and allometric equations in a tropical rainforest of Africa", Forest Ecology and Management, 260, Pages 1375-1388, 2010

[42] The Engineering ToolBox, "Density of various wood species", accessed on 15/11/2019 https://www.engineeringtoolbox.com/wood-density-d_40.html

[43] Glass S., Zalinka L., "The wood handbook: Wood as an engineering material, Chapter 4: Moisture relations and physical properties of wood", General Technical Report, USA, 2010

[44] Poletto M., Dettenborn J., Pistor V., Zeni M., Zattera A., "Materials produced from plant biomass, Part I: Evaluation of thermal stability and pyrolysis of wood", Materials Research, 13 (3), Pages 375-379, 2010, https://doi.org/10.1590/S1516-14392010000300016
[45] Poletto M., "Thermogravimetric analysis and kinetic study of pine wood pyrolysis", Brazilian Journal of Wood Science, 7(2), Pages 111-118, 2016

[46] Polymer Properties Database, accessed on 19/11/2019 http://polymerdatabase.com/polymer\%20physics/Polymer\%20Density.htm

[47] Scientific Polymers, Inc., accessed on 28/11/2019 https://scientificpolymer.com/density-of-polymers-by-density

[48] The Engineering ToolBox, "Polymers-Physical properties", accessed on $5 / 12 / 2019$ https://www.engineeringtoolbox.com/polymer-properties-d_1222.html

[49] Dos Santos W., De Sousa J., Gregorio Jr., "Thermal conductivity behaviour of polymers around glass transition and crystalline melting temperatures", Polymer Testing, 32, Pages 987-994, 2013

[50] Bernd W., Michael H., Frank S., "Thermal conductivity, thermal diffusivity, and specific heat capacity of particle filled polypropylene", Composites Part A: Applied Science and Manufacturing, Volume 35, Issue 4, Pages 423-429, Elsevier, 2004

[51] Xue L., Lope G., Ikechukwuka N., Satyanarayan P., "Thermal diffusivity, thermal conductivity, and specific heat of flax fiber-HDPE biocomposites at processing temperatures", Composites Science and Technology, 68, Pages 1753-1758, 2008

[52] Mediha K., Kadir D., Yildirim A., "Thermophysical properties of blend of Poly (Vinyl chloride) with Poly (Isobornyl Acrylate)", International Journal of Science \& Technology, Volume 3, No 1, Pages 37-42, 2008

[53] Mitsubishi Engineering-Plastics Corporation, "Thermal properties", Japan, 2018

www.m-ep.co.jp/en/pdf/product/iupi_nova/physicality_04.pdf

Ref.:

Mussa, Hadeel Mahmood - Salih, Tawfeeq Wasmi M.: Thermal conductivity of wood-plastic composites as insulation panels: theoretical and experimental analysis Épitőanyag - Journal of Silicate Based and Composite Materials, Vol. 73, No. 2 (2021), 54-62. p. https://doi.org/10.14382/epitoanyag-jsbcm.2021.9

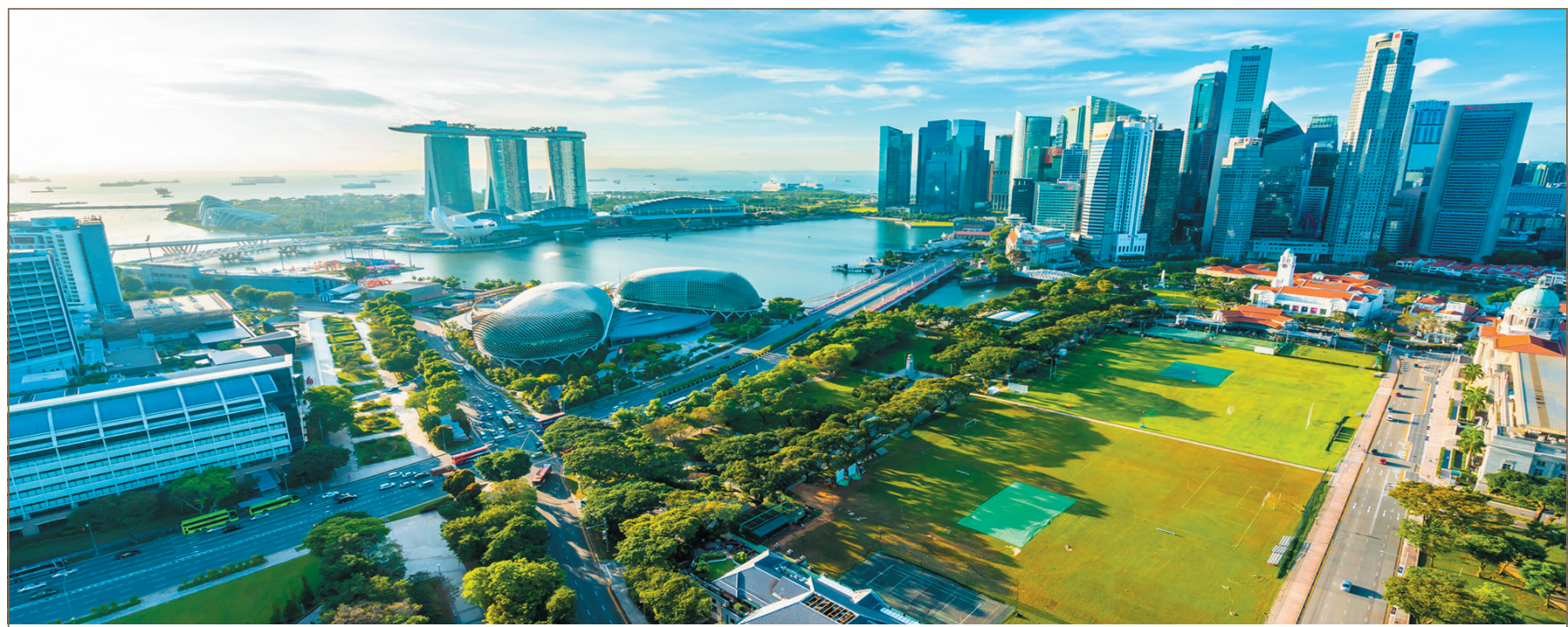

\section{ICCEN 2021}

$20219^{\text {th }}$ International Conference on Civil Engineering will be held during October 14-16, 2021 in Singapore.

ICCEN 2021 is co-sponsored by the Hong Kong Chemical, Biological \& Environmental Engineering Society (HKCBEES). It is one of the leading international conferences for presenting novel and fundamental advances in the fields of Civil Engineering. It also serves to foster communication among researchers and practitioners working in a wide variety of scientific areas with a common interest in improving Civil Engineering related techniques.

\section{wWw.iccen.org}

